\title{
A Young Patient with Acute Cauda Equina Syndrome Due to Traumatic Disc Herniation
}

\section{Genç Hastada Travmatik Disk Herniasyonuna Bağlı Gelişen Akut Kauda Ekuina Sendromu}

\author{
Nurşah Başol', Fatih Ersay Deniz², Erkan Gökçe³, Fatih Şahin'
}

'Department of Emergency Medicine, Gaziosmanpaşa University Faculty of Medicine, Tokat, Turkey 2Department of Neurosurgery, Gaziosmanpaşa University Faculty of Medicine, Tokat, Turkey ${ }^{3}$ Department of Radiology, Gaziosmanpaşa University Faculty of Medicine, Tokat, Turkey

\begin{abstract}
Introduction: Acute cauda equina syndrome (ACES) is a rare clinical condition. The etiologies of ACES are spinal hematoma, lumbar anesthesia, spinal manipulation, intraspinal tumor, infection, or lumbar disc herniation (LDH). ACES due to LDH is rare and reported to be $1 \%-2 \%$ of the cases.
\end{abstract}

Case Report: The case of a young patient with rapid onset of symptoms of ACES after trauma is presented.

Conclusion: It is aimed to show ACES due to $L D H$, which is a rare cause of ACES.

Keywords: Acute cauda equina syndrome, emergency, traumatic lumbar disc herniation

Received: 30.04.2015 Accepted: 06.07.2015

\section{ÖZET}

Giriş: Akut kauda ekuina sendromu klinikte nadir görülen bir durumdur. Etyolojisinde; spinal hematom, lomber anestezi, spinal girişimler, intraspinal yerleşimli tümörler, enfeksiyonlarveya lomber disk herniasyonları yer almaktadır. Lomber disk herniasyonuna bağlı gelişen akut kauda ekuina sendromu vakaların \%1-2'sinde olmak üzere nadiren görülmektedir.

Olgu Sunumu: Bu vakada, genç bir hastada travma sonrası gelişen ve hızlı belirti veren bir akut kauda ekuina sendromu sunuldu.

Sonuç: Bununla birlikte, klinikte nadir görülen bu duruma dikkat çekmek amaçlandı.

Anahtar Kelimeler: Anüri, akut böbrek yetmezliği, bilateral üreter taşı Geliş Tarihi: 30.04.2015 Kabul Tarihi: 06.07.2015

\section{Introduction}

Cauda equina syndrome (CES) occurs because of the compression of cauda equine, which is made up of nerve roots at the end of the spinal cord (1). CES is divided according to the onset of signs and symptoms. There is a rapid onset of clinical findings in acute CES (ACES) over hours or days, though chronic CES (CCES) occurs over months and years with progression (2). The pathophysiology and clinical signs and symptoms are similar in both ACES and CCES. The major clinical findings of ACES are low back pain, bilateral sciatica, saddle anesthesia, bladder/bowel dysfunctions, motor weakness of the lower extremities, and sexual dysfunction (3). ACES is a serious condition, and urgent surgery is mandatory. Thus, early diagnosis in the emergency department (ED) is very important. The etiologies of CES are epidural hematoma, lumbar anesthesia, spinal manipulation, intraspinal tumor, or infection. In addition, lumbar disc herniation $(\mathrm{LDH})$ can be a rare cause of CES. The percentage of $\mathrm{LDH}$ is reported to range range from $1 \%$ to $6 \%$ in studies $(1,4)$. Most patients with CES due to LDH have a history of back pain. Acute traumatic LDH is a very rare cause of ACES. Therefore, in this case, this rare cause of ACES is presented to draw attention.

\section{Case Report}

A 20-year-old male patient was admitted to ED with complaints of low back pain and numbness in the legs. He also described an altered urinary sensation and a poor urinary stream. According to the patient's statement, there was no history of low back pain and surgery. He stated that his complaints developed after he played a football match the previous day and progressed in 


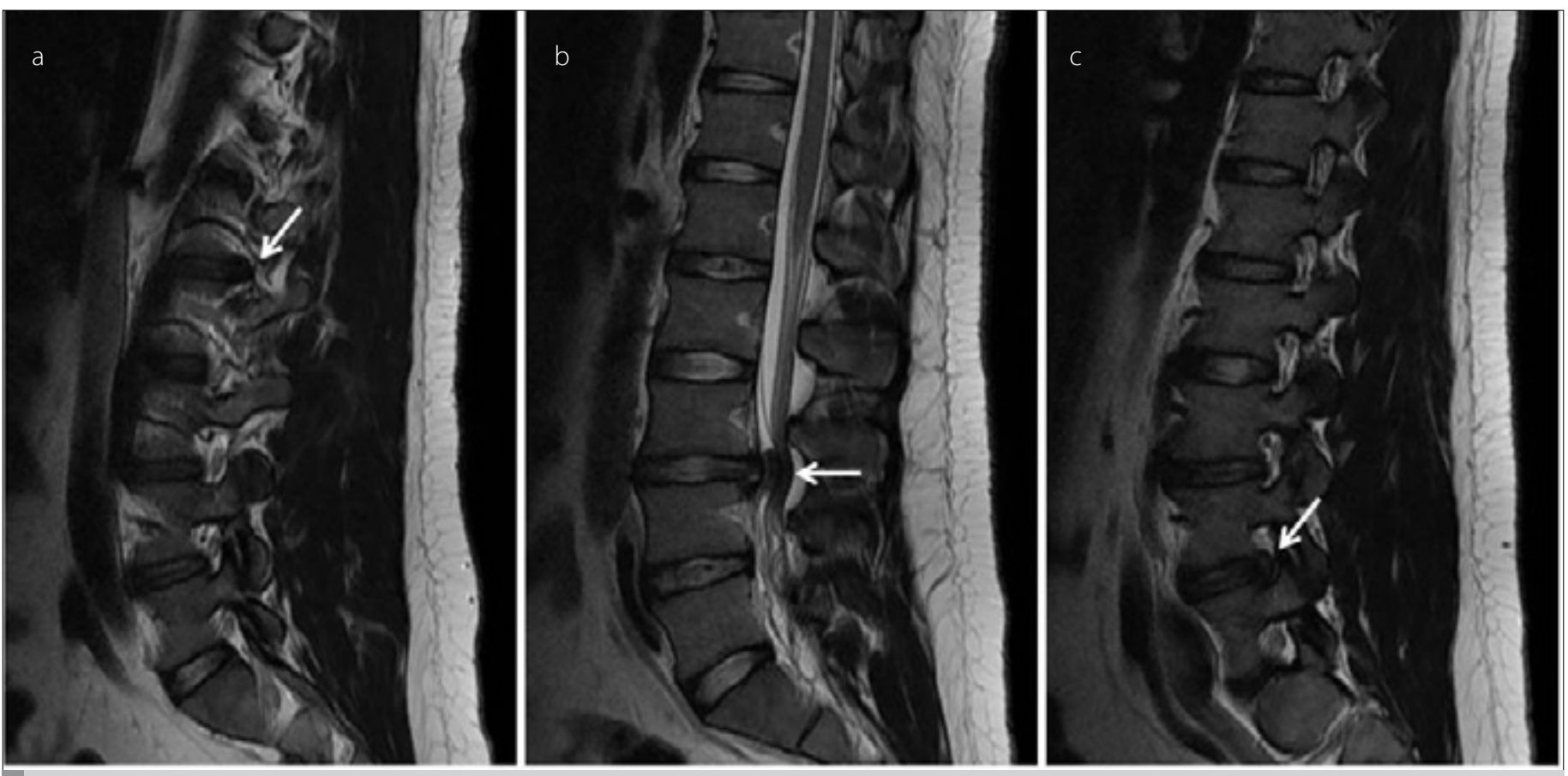

Figure 1. a-c. Sagittal plane T2-weighted MRI shows disc herniations in three levels. L1-L2 right lateral disc protrusion (a), L3-L4 posterior central protrusion (b), and L4-L5 left foraminal-lateral protrusion (c)
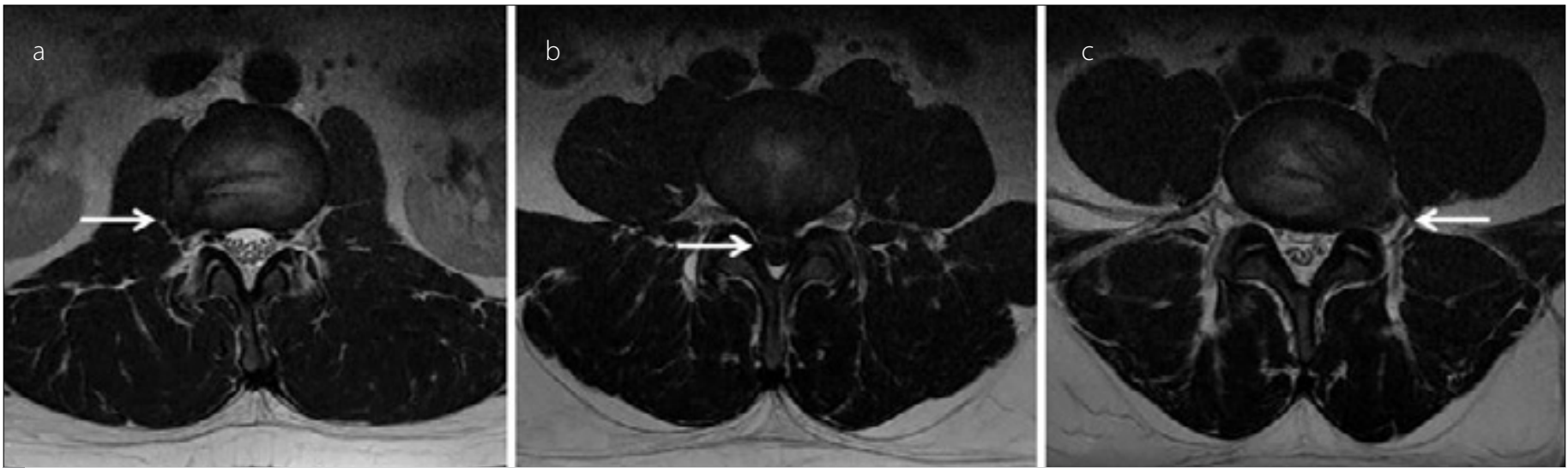

Figure 2. a-c. Axial plane T2-weighted MRI, L1-L2 right lateral disc protrusion (a), L3-L4 posterior central protrusion (b), and L4-L5 left foraminal-lateral protrusion (c)

few hours. In ED, his blood pressure was 110/70 mm Hg, pulse rate was 72 beats/min, respiration rate was 20/min, and his temperature was $36.8^{\circ} \mathrm{C}$. During his physical examination, there was bilateral L3S1 dermatomal hypoesthesia. Additionally, there was bilateral weakness of the lower extremities [the Medical Research Council (MRC) Scale for muscle strength was 3/5]. Other physical examination was normal. There was no pulse deficiency. His laboratory results were within normal ranges (biochemical analyses revealed the following: sodium $141 \mathrm{mmol} / \mathrm{L}$, potassium $4.49 \mathrm{mmol} / \mathrm{L}$, calcium $9.06 \mathrm{mg} / \mathrm{dL}$, and glucose $130 \mathrm{mg} / \mathrm{dL}$ ).

Lumbosacral magnetic resonance imaging (MRI) was performed, and $\mathrm{L} 1-\mathrm{L} 4$ right lateral protrusion, $\mathrm{L} 3-\mathrm{L} 4$ posterior central protrusion, and L4-L5 left foraminal-lateral protrusion (Figure 1 and 2) were detected. An emergency surgical excision of the $L 3-L 4$ disc extrusion was performed. His weakness improved after the second day of surgery (MRC scale was 4/5). Subsequently, he was discharged after 3 days with participation in the rehabilitation program.

\section{Discussion}

In this case, CES due to LDH was diagnosed with the help of the clinical findings and MRI images. In the differential diagnoses, electrolyte disturbances such as hypokalemia were ignored due to the normal laboratory results of the patient. The rapid progression of weakness can be seen in acute transverse myelitis. Besides, low back pain can be accompanied. However, there was no finding of transverse myelitis in the MRI findings in this case. Low back pain with weakness in the legs can be seen in Guillain-Barre syndrome (GBS), but there is no history of trauma in GBS, and the weakness began distally and soon spread proximally. Additionally, the patient had no recent history of infection, such as gastroenteritis. 
Cauda equina syndrome can be clinically diagnosed. It is reported that the sphincter activity of the bladder, which is controlled by lumbar and sacral nerves, is a major finding of CES (9). Besides, bowel disorders and sexual dysfunctions can be important signs of CES next to weakness of the lower extremities, bilateral sciatica, and saddle anesthesia. Diagnosis can be confirmed with these signs and by MRI. There was no finding of urinary retention, but the patient stated an altered urinary sensation and a poor urinary stream. Additionally, bowel functions and sexual functions were reported to be normal by the patient. The clinical findings were confirmed by MRI. The most common location for CES is L5- S1, and L3-L4 is the second common location (5, 10). In this case, the location was primarily in the $L 3-L 4$ intervertebral disc. There are several studies that evaluate the timing of surgery for ACES. It is reported that timing is important for ameliorating neurological dysfunctions (2). After the beginning of the symptoms, early surgery was performed in $24 \mathrm{~h}$ for this patient.

Only a few patients with CES present to ED with the first sign of LDH (4). Most patients with CES due to LDH have a history of $\mathrm{LDH}$, and the percentage was reported as 70\%-82\% $(4,5,8)$. Gooding et al. (6) suggested that CES can be seen in only $0.12 \%$ of patients with $\mathrm{LDH}$. Additionally, it was reported that $1 \%-2 \%$ cases of LDH may cause CES (7). Dogan et al. (8) evaluated 10 patients with CES due to LDH and reported that 5 patients (50\%) had a history of chronic low back pain. In this case, the patient had no history of LDH and/or low back pain.

It is suggested that disc herniation damages the cauda equina by three ways, including mechanical pressure, compromised microcirculation, and inflammation (2). Mechanical pressure on the cauda equina and nerve roots causes limb weakness and sphincter dysfunction in particular. Secondly, disc herniation leads to decreasing blood flow, and it can cause ischemia on nerve foots if it progresses. Lastly, disc lesions cause an inflammatory response in the cauda equine, which results in edema. Edema and chemical mediators affect nerve roots, and injury can happen. All these mechanisms are important for devising treatment plans (2).

\section{Conclusion}

Acute cauda equina syndrome is an uncommon and important neurological condition that should be diagnosed early in ED. It should be considered in patients with low back pain absence or presence of the history of LDH, whenever acute neurological symptoms are presented.

Informed Consent: Written informed consent was obtained from patient who participated in this case.

Peer-review: Externally peer-reviewed.

Author Contributions: Concept - N.B.; Design - N.B.; Supervision F.E.D.; Materials - F.Ş., E.G.; Data Collection and/or Processing - E.G., F.Ş.; Analysis and/or Interpretation - N.B., F.E.D.; Literature Review N.B., F.E.D.; Writer - N.B.; Critical Review - F.E.D.
Conflict of Interest: The authors declared no conflict of interest.

Financial Disclosure: The authors declared that this study has received no financial support.

Hasta Onamı: Yazılı hasta onamı bu olguya katılan hastadan alınmıştır.

Hakem değerlendirmesi: Dış bağımsız.

Yazar Katkıları: Fikir - N.B.; Tasarım - N.B.; Denetleme - F.E.D.; Malzemeler - F.Ş., E.G.; Veri toplanması ve/veya işlemesi - E.G., F.Ş.; Analiz ve/ veya yorum - N.B., F.E.D.; Literatür taraması - N.B., F.E.D.; Yazıyı yazan - N.B.; Eleştirel İnceleme - F.E.D.

Çıkar Çatışması: Yazarlar çıkar çatışması bildirmemişlerdir.

Finansal Destek: Yazarlar bu çalışma için finansal destek almadıklarını beyan etmişlerdir.

\section{References}

1. Kusakabe T. Cauda equina syndrome. Orthopaedics and Trauma 2013; 27: 215-9. [CrossRef]

2. Mahadevappa K, Persi A, Nesathurai S. Acute cauda equına syndrome caused by a disk lesıon: is emergent surgery the correct optıon? Spine (Phila Pa 1976) 2015; 40: 636-8. [CrossRef]

3. Jun W, Yi-Jun K, Xiang-Sheng Z, Jing W. Cauda equina syndrome caused by a migrated bullet in dural sac. Turk Neurosurg 2010; 20: 566-9.

4. Sonntag VK. Why not decompress early? The cauda equina syndrome. World Neurosurg 2014; 82: 70-1. [CrossRef]

5. Ahn UM, Ahn NU, Buchowski JM, Garrett ES, Sieber AN, Kostuik JP. Cauda equina syndrome secondary to lumbar disc herniation: a metaanalysis of surgical outcomes. Spine (PhilaPa 1976) 2000; 25: 1515-22. [CrossRef]

6. Gooding BW, Higgins MA, Calthorpe DA. Does rectal examination haveany value in the clinical diagnosis of cauda equina syndrome? $\mathrm{Br} J$ Neurosurg 2013; 27: 156-9. [CrossRef]

7. Chau AM, Xu LL, Pelzer NR, Gragnaniello C. Timing of surgical intervention in cauda equina syndrome: a systematic critical review. World Neurosurg 2014; 81: 640-50. [CrossRef]

8. Doğan \$̧, Türkan A, Caner B, Kaplan T, Bekar A. bel Ağrısında Acil Bir Durum: KaudaEquina Sendromu İle Kendini Gösteren Lomber Disk Hernisi. Uludağ Üniversitesi Tıp Fakültesi Dergisi 2007; 33: 141-4.

9. Tamburrelli FC, Genitiempo M, Bochicchio M, Donisi L, Ratto C. Cauda equina syndrome: evaluation of the clinical outcome. Eur Rev Med Pharmacol Sci 2014; 18: 1098-105.

10. Karataş $A$, İ̧ M, Yıldız H, Gezen F. Lomber Disk Herniasyonuna Bağlı Inkomplet Kauda Ekuina Sendromu. Cerrahpaşa Tıp Dergisi 2006; 37 106-9.5 